\title{
COMPARISON OF CLTD AND TETD COOLING LOAD CALCULATION METHODS FOR DIFFERENT BUILDING ENVELOPES
}

\author{
*Hasan Oktay, Mechanical Engineering, Batman University, Turkey, oktayhasan50@gmail.com \\ (iD) https://orcid.org/ 0000-0002-0917-7844) \\ Recep Yumrutaş, Mechanical Engineering, University of Gaziantep, Turkey, yumrutas@gantep.edu.tr \\ (iD) https://orcid.org/ 0000-0001-9006-198X) \\ M. Zerrakki Işılk, Mechanical Engineering, Batman University, Turkey, tuyman21@hotmail.com \\ (iD) https://orcid.org/ 0000-0001-9753-6458) \\ Research Article \\ DOI: $10.22531 /$ muglajsci.631222
}

Received: 19.10.2019, Accepted: 13.01.2020

* Corresponding author

\begin{abstract}
The estimation of the cooling load through the building envelope is an essential task in the selection of proper HVAC system components that influences the building's performance. For this task, ASHRAE has presented several methods to calculate the building cooling load due to heat gain, such as the total equivalent temperature difference method (TETD), the cooling load temperature difference method (CLTD), and the radiant time series method (RTS). The present study aims to explore the accuracies of those calculation methods in terms of energy efficiency. In this regard, an analytical solution method utilizing Complex Finite Fourier Transform Technique (CFFT) was developed for the calculation of cooling load due to heat gain to compare the temperature differences obtained from the TETD and CLTD methods. Then, a computer program was prepared in MATLAB to perform the calculations based on an analytical methodology. Besides, the estimated CLTD and TETD values by the CFFT were compared with those values presented in the Handbook of the ASHRAE. The calculation results revealed there is a good agreement between the analytical and presented results in the ASHRAE Manual for the selected building envelopes. However, several differences were found between the estimated TETD and CLTD cooling load values and those presented in the Handbook of ASHRAE.
\end{abstract}

Keywords: Building envelope, cooling load, heat gain, cooling load calculation methods

\section{FARKLI BİNA YAPI ELEMANLARI İÇİN CLTD VE TETD SOĞUTMA YÜKÜ HESAPLAMA YÖNTEMLERININ KARŞILAŞTIRILMASI}

\section{Özet}

Bina yapı elemanlarından kaynaklı soğutma yükünün doğru bir şekilde hesaplanması, binanın performansını etkileyen uygun HVAC sistem bileşenlerinin seçiminde önemli bir görevdir. Bu görev için ASHRAE, bina ISı kazancından kaynaklı soğutma yükünü hesaplamak için, soğutma yükü sıcaklık farkı yöntemi (CLTD), toplam eşdeğer sicaklık farkı yöntemi (TETD) ve radyant zaman serisi yöntemi (RTS) gibi çeşitli yöntemler sunmuştur. Bu çalışma, bu hesaplama yöntemlerinin enerji verimliliği açısından doğruluğunu araştırmayı amaçlamıştır. Bu bağlamda, CLTD ve TETD yöntemlerinden elde edilen sıcaklık farklarını karşılaştırmak için karmaşık sonlu Fourier dönüşüm tekniği (CFFT) kullanılarak ısı kazancından kaynaklı soğutma yükünü hesaplayan analitik bir çözüm yöntemi geliştirilmiştir. Matematiksel çözüme dayalı bir hesaplama yöntemi geliştirilmiş olup, sayısal hesaplamalar için ise Matlab'da bir bilgisayar programı hazırlanmıştır. Bunun yanında, CFFT tarafından hesaplanan CLTD ve TETD değerleri ASHRAE El kitabı tarafindan sunulan değerlerle karşılaştırılmıştır. Seçilen bina yapı elemanları için hesaplanan sonuçlar ile ASHRAE tarafından verilen değerler arasında önemli bir uygunluk olduğu görülmüştür. Ayrıca hem hesaplanan hem de ASHRAE El kitabı tarafindan sunulan TETD ve CLTD soğutma yükü değerleri arasında çeșitli farklılıklar tespit edilmiștir.

Anahtar Kelimeler: Bina yapı elemanları, soğutma yükü, ısı kazancı, soğutma yükü hesaplama yöntemleri

Cite

Oktay, H., Yumrutaş, R., Işık, M. Z., (2020). “Comparison of CLTD and TETD cooling load calculation methods for different building envelopes", Mugla Journal of Science and Technology, 6(1), 18-26.

\section{Introduction}

The building sector is responsible for the great amount of total energy consumption in the World. Most of this energy is used for the provision of heating and cooling applications. The main objective of a cooling or heating system is to maintain the conditions that are required for indoor products and processes and to provide thermal comfort conditions to the occupants of the building. The heat rate that must be removed from a room to maintain a constant temperature at the comfort level is defined as 
cooling load [1]. The heat gain through the building envelope, which includes roofs and walls in most buildings, constitutes a significant partition of the overall cooling load of space due to its large area [2]. If an accurate cooling load calculation is performed, then the cooling load due to heat gain can decrease, and a suitable HVAC system can be selected. An accurate calculation of the cooling load is quite complicated and time consuming due to the thermal storage effects of a building thermal mass and continuously changing outdoor climatic conditions. In order to eliminate such problems, many methods are developed to calculate the cooling considering the thermal mass of a building, the hourly changing of outdoor conditions, the heat loss coefficient of the building, as well as solar radiation incident [3]. In literature, several methods have been developed, such as total equivalent temperature difference method (TETD), transfer function method (TFM), heat balance method (HB), and cooling load temperature difference method (CLTD) to estimate the cooling load of a building due to heat gain. TFM, which is widely used in the HVAC industry [4], uses a series of estimated conduction transfer functions (CTF) coefficients tabulated in the ASHRAE handbook for specific types of ceilings, walls, and floors [5]. The calculation of heat gain by the CLTD method is provided by multiplying the UA value of the building envelope with the CLTD values obtained by using the HB or TFM technique. It is limited by the data for specific constructions used in North America with particular external conditions [2]. Although ASHRAE has recommended correction factors in the calculation of standard CLTD values for the above conditions, the accuracy of the CLTD values is questionable for locations outside $40^{\circ} \mathrm{N}$, in particular for locations below $24^{\circ} \mathrm{N}$ [6]. Another method proposed by ASHRAE is the TETD method, considering the transient effects of thermal storage and solar energy, is an alternative technique of the heat balance method that utilizes the average time (TA) of the total equivalent temperature difference (TETD) to calculate cooling load due to heat gain. In the TETD method, the response factor method is used to calculate TETD values as a function of inside air and solar air temperatures for a series of representative walls and ceilings. Alford et al. [7] developed an analytical method for calculating the interior surface temperature of a homogeneous structure under conditioned conditions, and Mackey and Wright [8] similarly derived mathematical formulations for homogeneous walls or roofs, later the expressions were expanded to include composite structures [9]. Alford et al. describe the decrement factor as the ratio of the amplitude of the interior surface heat flux to the amplitude of the exterior sol-air temperature; however, Mackey and Wright [8] defined the decrement factor as the ratio of the amplitude of the inner surface temperature of the building structure to the amplitude of the external sol-air temperature.

Several studies have been carried out to extend the utilization of TETD and CLTD for a wide range of building envelopes in different climatic conditions. Bansal et al. [2] developed a numerical model utilizing a finite difference method to simulate the transient thermal behavior of multi-layered walls and flat roofs. In their study, several notable differences have been found between numerically estimated CLTD and those given in the ASHRAE handbook [5]. In order to estimate the TETD values for multi-layer walls and flat roofs, Yumrutas et al. [10] developed an analytical model based on the solution of the periodic heat transfer model. Besides, TETD values were obtained for each wall and roof in Gaziantep (37.1 ${ }^{\circ} \mathrm{N}$ ) by using the measured values of sol-air temperature, time lag, decrement factor, and solar radiation incident. In order to estimate the thermal behavior of multilayered walls under realistic external conditions, Ruivo et al. [11] numerically developed a periodic heat transfer model. They found that the time lag is significantly affected by the azimuth of the wall. Zainal and Yumrutas [12] used the CFFT technique to find the CLTD values for multi-layered roofs and walls numerically. The solution of the transient problem is a new approach to estimate CLTD values. Moreover, CFFT is applicable for any possible building structure and ever-changing outdoor climatic conditions, and also it does not require the tables.

Although many researchers have attempted to use different methods for calculating the cooling load by CLTD and TETD method, there has not been much research about identifying the degree of similarity and comparison to each other. Furthermore, some contradictory or inconclusive results exist in the literature about using the decrement factor and the time lag during the calculation of TETD values. Furthermore, it is necessary to develop analytical models that can be applied to any possible structure without using tables. Therefore, this research aims to develop an analytical solution method utilizing a complex finite Fourier transform (CFFT) method for the calculation of cooling load due to heat gain through the walls and flat roofs exposed to realistic climatic conditions and to compare the temperature differences obtained from the CLTD and TETD methods. Besides, the generated CLTD and TETD values by CFFT are compared with the CLTD presented in the ASHRAE manual.

\section{Description of cooling load and calculation procedure}

Human beings only sense well and comfortably within a narrow range of thermal conditions. A building is an enclosure that protects against external conditions. It should provide a comfortable environment on the inside. Heat loss or gain is a very significant factor in the operation of a building depending on the building structure, which includes walls, floors, ceilings, and external parts of a building. Commonly these parts are referred to as the building envelope [13]. The heat rate that must be removed from a room to maintain a constant temperature at the comfort level is defined as cooling load, as stated before. The cooling load generally differs from 
the heat gain since the radiation from the interior surface of walls or roofs and objects, and also the solar radiation incident coming directly through space, does not directly heat the air within the space. In order to provide an accurate, consistent, and convenient method of estimating those loads and to enable the designer to choose systems that meet the requirements for efficient energy utilization. The phenomenon of cooling load, heat gain as well as descriptions of calculation methods of CLTD/CLF and TETD/TA are illustrated in Figure 1 [14].

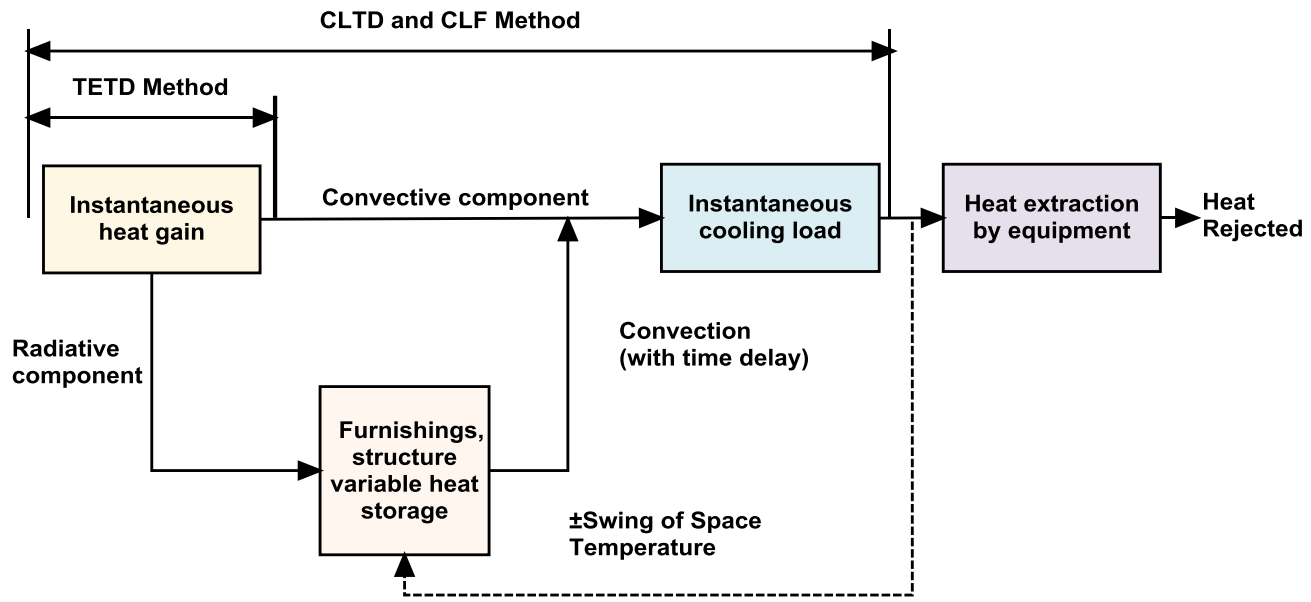

Figure 1. Schematic of Load Transfer [1]

In order to calculate cooling loads, cooling load temperature differences (CLTD), solar cooling load factors (SCL), and internal cooling load factors (CLF) are one-step procedures of the simplified version of the TFM, which can be used with certain types of buildings where application data is available, was presented in the 1977 ASHRAE Handbook of Fundamentals [15]. On the other hand, total equivalent temperature differential values and a system of time-averaging (TETD/TA) are procedures of the simplified version of the heat balance technique that was first introduced in the 1967 ASHRAE Handbook of Fundamentals to calculate cooling loads [16]. The procedure for calculating cooling load by CLTD/CLF and TETD/TA methods for a building envelope is summarized in Table 1.

Table 1. Summary of CLTD/CLF and TETD/TA Load Calculation Procedures [17]

\begin{tabular}{|c|c|c|}
\hline & Equation & Reference, Table, Description \\
\hline \multirow[t]{2}{*}{$\begin{array}{l}\text { Roofs, walls, } \\
\text { conduction } \\
\text { through glass }\end{array}$} & $q=U A(\mathrm{CLTD})$ & $\begin{array}{l}U=\text { heat transfer coefficient for roof or wall from Chapter } 24 \text { in } \\
\quad \text { Table } 4 \text {; or glass, Chapter } 29 \text {, in Table } 5 \\
A=\text { area of roof, wall, or glass } \\
\text { CLTD = cooling load temperature difference for aroof, wall, or } \\
\text { aglass }\end{array}$ \\
\hline & $\begin{array}{c}q=U A(\mathrm{TETD}) \\
\mathrm{TETD}=t_{e a}-t_{i}+\lambda\left[t_{e \delta}-t_{e a}\right]\end{array}$ & $\begin{array}{l}U=\text { heat transfer coefficient for roof or wall, from Chapter } 24 \text {, in } \\
\quad \text { Table } 4 \\
A=\text { area of roof or wall } \\
\text { TETD = total equivalent temperature difference for roof or wall } \\
t i=\text { interior design dry-bulb temperature } \\
\lambda=\text { decrement factor, from Table } 14 \text { or } 19 \\
t_{e \delta}=\text { sol-air temperature at time lag } \delta \text { hours previous to } \\
\text { calculation hour (Table } 14 \text { or } 19 \text { ) }\end{array}$ \\
\hline $\begin{array}{l}\text { Partitions, } \\
\text { ceilings, floors }\end{array}$ & $q=U A\left(t_{b}-t_{i}\right)$ & $\begin{array}{l}U=\text { heat transfer coefficient for roof or wall from Chapter } 24, \text { in } \\
\quad \text { Table } 4 \\
A=\text { area of partition, ceiling, or floor } \\
t_{b}=\text { temperature in adjacent space } \\
t_{i}=\text { inside design temperature in conditioned space }\end{array}$ \\
\hline
\end{tabular}

\section{Formulation of the transient heat transfer problem}

Heat is transferred from a building structure through the room as a function of the interior wall surface and solarair temperature. The heat flux passing through the room can be calculated using the inner surface temperature, the combined heat transfer coefficient (radiation + convection) on the surface, and the room temperature. Figure 2 shows a schematic representation of a multilayered wall or flat roofs. 


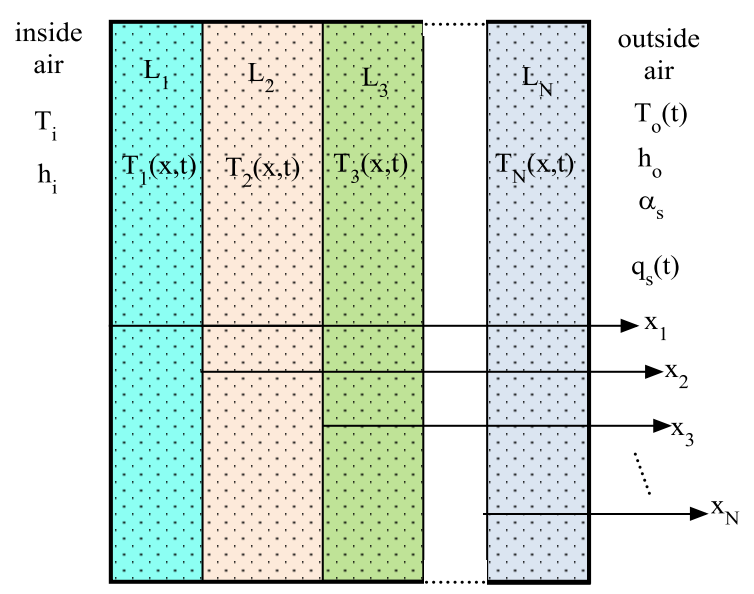

Figure 2. A schematic representation of a multi-layered wall

The periodic heat transfer from a building structure to a room is presented as the following partial equations under given boundary conditions:

$$
\begin{gathered}
\frac{\partial^{2} T_{n}}{\partial x_{n}^{2}}=\frac{1}{\alpha_{n}} \frac{\partial T_{n}}{\partial t} \\
h_{i}\left(T_{r}-T_{1}\right)=-k_{1} \frac{\partial T_{1}}{\partial x_{1}}\left(x_{1}=0\right) \\
k_{n-1} \frac{\partial T_{n-1}}{\partial x_{n-1}}\left(x_{n-1}=L_{n-1}\right)=k_{n} \frac{\partial T_{n}}{\partial x_{n}}\left(x_{n}=0\right) \\
\mathrm{T}\left(x_{n-1}=L_{n-1}\right)=\mathrm{T}\left(x_{n}=0\right) \\
-k_{N} \frac{\partial T_{N}}{\partial x_{N}}\left(x_{N}=L_{N}\right)=h_{o}\left[T_{N}-T_{e}(t)\right] \\
T_{e}(t)=T_{a}(t)+\frac{\alpha_{s} I_{t}(t)}{h_{o}}-\frac{\varepsilon \Delta R}{h_{o}}
\end{gathered}
$$

where $\alpha_{\mathrm{s}}$ is the absorptivity of the surface, $\alpha_{\mathrm{n}}$ is the thermal diffusivity, $\mathrm{k}$ is the thermal conductivity, and $\mathrm{T}_{\mathrm{a}}(\mathrm{t})$ is the hourly ambient air temperatures. Sol-air temperature, $\mathrm{T}_{\mathrm{e}}(\mathrm{t})$ given in Eq. 6. is the temperature of the ambient air that gives the same amount of heat input into the surface in the absence of all radiation changes as the combination of solar radiation, radiant energy exchange with the sky and outdoor environment, and convective heat exchange with the ambient air [17]. $\mathrm{I}_{\mathrm{t}}(\mathrm{t})$ is the hourly incident solar radiation incident on the surface, $h_{i}$ and $h_{o}$ are the combined convection heat transfer coefficients at the inner and outer surfaces, respectively. $\Delta \mathrm{R}$ is the difference between the long-wave radiation incident from the sky and the radiation incident emitted by a blackbody at the ambient air temperature. ASHRAE recommends the correction factor, $\varepsilon \Delta R / h_{o}$ to be given a value of $4^{\circ} \mathrm{C}$ and $0^{\circ} \mathrm{C}$ for horizontal surfaces and vertical surfaces, respectively [17].
The transient heat transfer problem given in Eqs. (1) - (6) is transformed into dimensionless formulations, and then CFFT is applied to the heat transfer problem. The dimensionless formulation is solved to obtain the transient solution, as detailed in Yumrutas et al. [3,10]. A general solution equation giving temperature distribution through a building wall or roof is expressed as:

$$
T_{n}\left(z_{n}, \tau\right)=\sum_{j=-M}^{M} T_{n j}\left(z_{n}\right) e^{i 2 \pi j \tau}
$$

where $\mathrm{Zn}_{\mathrm{n}} \tau$, and $\mathrm{T}_{\mathrm{nj}}$ are dimensionless parameters. $\mathrm{M}$ is the large number and generally taken as 60 . Also, $\mathrm{q}$ is the heat gain $\left(\mathrm{W} / \mathrm{m}^{2}\right)$ through the indoor space of a building from exterior walls. It can be calculated using the inner wall surface, and $\mathrm{T}_{\mathrm{r}}$, room temperature and combined convection heat transfer coefficient at the inner surface, $\mathrm{h}_{\mathrm{i}}$ :

$$
\mathrm{q}=h_{i}\left[T_{n}(0, \tau)-T_{r}\right]
$$

where $T_{n}(0, \tau)$ is the inner surface temperature of the roof or wall obtained from Eq. (7) at $\mathrm{Z}_{n}=0$, and $U$ is the coefficient of overall heat transfer for a wall or roof. Thus, CLTD can be calculated as:

$$
\operatorname{CLTD}=\frac{h_{i}}{U}\left[T_{n}(0, \tau)-T_{r}\right]
$$

Although TETD is calculated like CLTD with the same basic heat transfer equation, the approximate solution of TETD presented by Mackey and Wright [9] can be estimated by the heat transfer solution [11]:

$$
\operatorname{TETD}=T_{e a}-T_{r}+\frac{h_{i}}{U} \lambda\left[T_{e \delta}-T_{e a}\right]
$$

where $\lambda$ and $\delta$ are decrement factor (DF) and time lag (TL) with respect to the external sol-air temperature, respectively. $\mathrm{T}_{\mathrm{e} a}$ and $\mathrm{T}_{\mathrm{e} \delta}$ are daily average sol-air temperature and sol-air temperature time lag hours ago, respectively. The $\delta$ and $\lambda$ are significant characteristics of a building envelope to identify their heat storage capabilities. $\delta$ and $\lambda$ are estimated as:

$$
\delta=t_{T_{i, \max }}-t_{T_{e, \max }} \text { and } \lambda=\frac{T_{i, \max }-T_{i, \min }}{T_{e, \max }-T_{e, \min }}
$$

where $t_{T i, \max }$ and $\mathrm{t}_{\mathrm{Te} \text {,max }}$ represent the times when interior surface and sol-air and temperatures are at their maximums, respectively. Also, $\mathrm{T}_{\mathrm{i}, \max }, \mathrm{T}_{\mathrm{i}, \min }, \mathrm{T}_{\mathrm{e}, \max }$, and $\mathrm{T}_{\mathrm{e}, \min }$ are the minimum and maximum temperatures on both of the inner surface and sol-air temperatures, respectively. When derivatives of Eqs. (6) - (7) are set equal to zero, the highest and the lowest temperatures, and also the time can be obtained.

\section{Results and discussion}

In this study, an analytical model is developed to calculate TETD and CLTD values of building multi- 
layered walls and roofs for any time and place. Various walls and flat roofs have been selected for the comparison of CLTD and TETD values. In order to perform the calculations numerically, a computer program in MATLAB is designed [18]. While performing the calculations, all thermophysical properties of the selected walls or roofs, indoor and outdoor climatic conditions (room and hourly sol-air temperatures), are used as inputs and taken from the Handbook of ASHRAE [17]. The room temperature, outside, and inside surface resistances are accepted to be $25.5^{\circ} \mathrm{C}, 0.059 \mathrm{~W} / \mathrm{m}^{2 \circ} \mathrm{C}$, and $0.121 \mathrm{~W} / \mathrm{m}^{2}{ }^{\circ} \mathrm{C}$, respectively. The outer surfaces of the constructions are assumed to be dark-colored, hence $\alpha /$ ho is taken as 0.052 . Furthermore, the hourly sol-air temperatures in Eq. (6) are calculated by utilizing the data for hourly ambient air temperatures and solar radiation incident on the tilted surfaces presented in the 1997 ASHRAE Handbook of Fundamentals [17] (Figure $3)$. For the horizontal surface, solar-air temperatures reach the highest values due to the existence of the highest solar radiation on that surface. Since higher values of ambient air temperature and solar radiation exist in the afternoon, the temperature of the West wall is higher than the East wall.

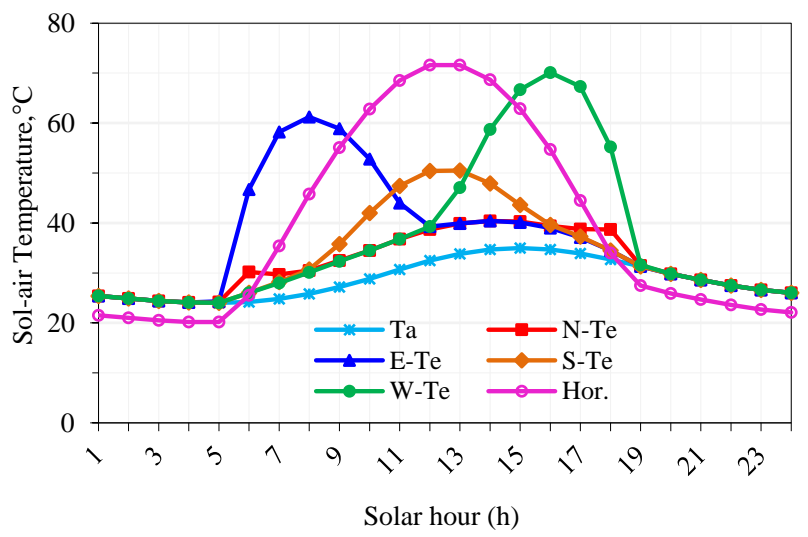

Figure 3. Daily variations of sol-air temperatures for horizontal and four main directions

\subsection{Validation of the present model}

In order to show the reliability of the present model, a comparison for the solution method has been made between given in ASHRAE and obtained by CFFT for the given walls and flat roofs. Table 2 shows the characteristics of the walls or roofs used in the calculations in this study.

Table 2. Characteristics of the selected wall and roofs taken from the Handbook of ASHRAE $[17,19]$

\begin{tabular}{ccc}
\hline $\begin{array}{c}\text { Construction } \\
\text { type }\end{array}$ & $\begin{array}{c}\text { Specification of } \\
\text { construction }\end{array}$ & $\begin{array}{c}\mathrm{U} \text {-value, } \\
\mathrm{W} / \mathrm{m}^{20} \mathrm{C}\end{array}$ \\
\hline Roof 1 & $\begin{array}{c}\text { Steel deck w/85 mm } \\
\text { insulation } \\
50 \text { mm gypsum }\end{array}$ & 0.456 \\
Roof-ex. & $\begin{array}{c}5 \text { slab on metal roof deck } \\
\text { w/50 mm insulation }\end{array}$ & 0.510 \\
&
\end{tabular}

\begin{tabular}{ccc}
$\begin{array}{c}\text { Wall-ex. } \\
\text { (South wall } \\
\text { cons.) }\end{array}$ & $\begin{array}{c}360 \mathrm{~mm} \text { brick, w/16 mm } \\
\text { plaster, }\end{array}$ & 1.360 \\
$\begin{array}{c}\text { Wall-ex. } \\
\text { (East and } \\
\text { North wall } \\
\text { cons.) }\end{array}$ & $\begin{array}{c}\text { 200 mm h.w. concrete } \\
\text { block, w/16 mm plaster, }\end{array}$ & 2.730 \\
Wall 1 & $\begin{array}{c}\text { Steel siding with } 100 \mathrm{~mm} \\
\text { insulation }\end{array}$ & 0.372 \\
Wall 3 & $\begin{array}{c}100 \text { mm h.w. concrete } \\
\text { block with } 25 \text { mm } \\
\text { insulation }\end{array}$ & 1.085 \\
Wall 9 & $\begin{array}{c}150 \text { mm insulation with } \\
\text { 50 mm wood }\end{array}$ & 0.241 \\
Spandrel wall & $\begin{array}{c}16 \text { mm gypsum wall with } \\
\text { mineral fiber insulation }\end{array}$ & 0.450 \\
\hline
\end{tabular}

In order to show the validity of the TETD method, firstly, TL, and DF values should be verified. Hence, TL and DF values obtained by the present method are compared with Mackey and Wright's method [8,9]. Mackey and Wright developed an analytical method for calculating the interior surface temperature of a homogeneous structure, and the expressions were later expanded to include composite structures under conditioned conditions [9]. The specified method provides acceptable accuracy results with external excitation. Table 3 shows the comparison of TL and DF values for the selected wall types in Mackey and those obtained from the present study. When the results are compared to each other, it can be observed that the maximum relative error between the results of the present study and Mackey and Wright's model $(0.45 \%$ for DF and $3.85 \%$ for TL) is very small. The results show that the obtained TL and DF values by the present and Mackey and Wright's models are in good agreement.

Table 3. Comparison of the models for the calculation of the time lag (TL) and decrement factor (DF) for the selected multilayer walls.

\begin{tabular}{cccccc}
\hline $\begin{array}{c}\text { Wall } \\
\text { number }\end{array}$ & $\begin{array}{c}\text { Layer } \\
\text { number }\end{array}$ & \multicolumn{2}{c}{$\begin{array}{c}\text { Mackey and } \\
\text { Wright method }\end{array}$} & \multicolumn{2}{c}{$\begin{array}{c}\text { Present paper by } \\
\text { CFF method }\end{array}$} \\
& & TL (hr) & DF & TL (hr) & DF \\
\hline 1 & 2 & 4.52 & 0.1613 & 4.46 & 0.1610 \\
26 & 2 & 15.8 & 0.0147 & 15.79 & 0.0148 \\
27 & 2 & 24 & 0.0019 & 23.88 & 0.0019 \\
28 & 2 & 8.47 & 0.0658 & 8.43 & 0.0663 \\
29 & 2 & 12.6 & 0.0249 & 12.53 & 0.0251 \\
31 & 3 & 3.28 & 0.2142 & 3.25 & 0.2148 \\
32 & 3 & 12.2 & 0.0219 & 12.18 & 0.0219 \\
33 & 3 & 4.6 & 0.1612 & 4.46 & 0.1613 \\
34 & 3 & 3.6 & 0.1858 & 3.49 & 0.1862 \\
\hline
\end{tabular}

In order to compare the CLTD and TETD values, different compositions of two flat roofs (Roof 1 for CLTD and roof in example for TETD) and two walls (Wall 1 for CLTD and 
wall in example for TETD) are selected from the 1997 ASHRAE Handbook of Fundamentals [17]. Figure 4 shows the hourly variation of CLTD and TETD values in the ASHRAE manual and the values obtained by CFFT for the selected roofs. The curves are almost identical. This figure depicts that the variation of CLTD and TETD values estimated by the present model are close to those values given in ASHRAE both of roofs. The average daily difference in CLTD values is about $1.1^{\circ} \mathrm{C}$, and the average daily difference in TETD values is about $1^{\circ} \mathrm{C}$.

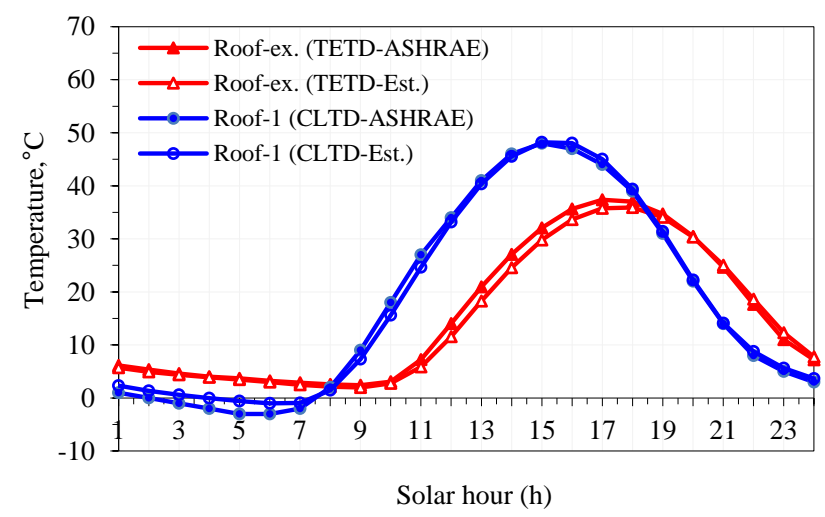

Figure 4. Comparison of CLTD and TETD values estimated by CFFT and given in ASHRAE 1997 [17] for the selected roofs

In the case of the walls, which are Wall 1 for CLTD and wall in example for TETD, are selected to compare CLTD and TETD values given in the ASHRAE manual due to four main directions. The curves for estimated CLTD values follow the curves for those values presented in the 1997 ASHRAE Handbook of Fundamentals [17], as shown in Figure 5. This figure depicts that the estimated CLTD values obtained by CFFT and those values given in the ASHRAE manual are very close to each other. However, some differences exist between the estimated and presented values. The average daily differences in CLTD values are obtained as $0.6^{\circ} \mathrm{C}, 1^{\circ} \mathrm{C}, 1.1^{\circ} \mathrm{C}$, and $0.6^{\circ} \mathrm{C}$ for North, South East, and West facing walls, respectively.

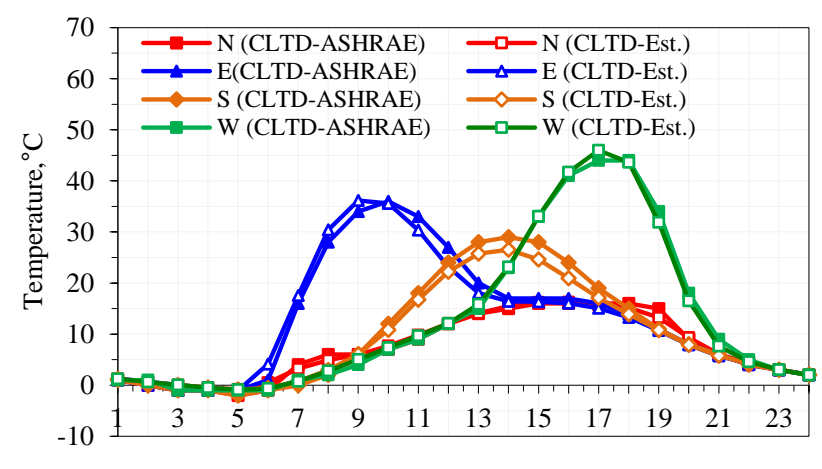

Solar hour (h)

Figure 5. Comparison of CLTD values estimated by CFFT and given in ASHRAE 1997 [17] for Wall 1 due to main directions.

In order to compare TETD values calculated by CFFT and the values presented by the ASHRAE manual, the wall in the example of ASHRAE is selected and directed to East, South, and North directions, as depicted in Figure 6. The curves for estimated TETD values follow the curves for those values presented in the ASHRAE manual except for East direction. Besides, there is a phase difference of about two hours for East direction. The average daily differences in TETD values are obtained as $0.8{ }^{\circ} \mathrm{C}, 1.4{ }^{\circ} \mathrm{C}$ and $0.2{ }^{\circ} \mathrm{C}$ for North, East, and South facing walls, respectively. These differences are due to using the transfer function coefficients for calculating temperature values in the ASHRAE model.

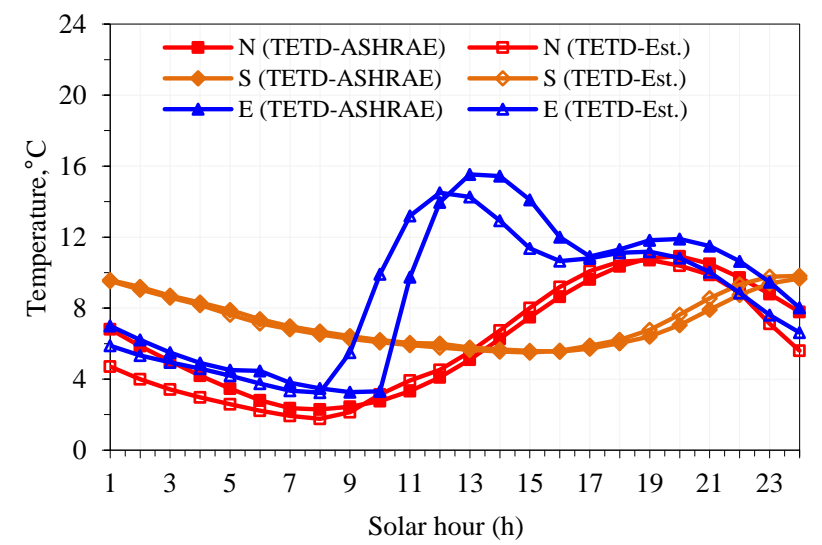

Figure 6. Comparison of TETD values estimated by CFFT and given in ASHRAE 1997 [17] for Wall 1 due to main directions.

The results show that the differences in both methods are reasonably low. The consistency of the calculated values for both TETD and CLTD with the method presented in the study shows the validity of the solution method. However, some differences exist between the estimated values. The main reason is that the solution method used present study and presented by ASHRAE are different from each other. In the study, the CFFT method is used to calculate the inner surface temperatures of the wall or flat roofs, while in the ASHRAE model, TFM (transfer function method) is used to calculate the temperature values. Hence, there are some differences in the number of terms and used transfer function coefficients for each structure.

\subsection{Comparison of estimated cooling load calculation methods}

Figure 7 shows comparisons of the estimated values of CLTD and TETD by CFFT with the values of CLTD and TETD obtained from ASHRAE for Wall 1. When the results are compared, the average daily differences between CLTD and TETD values are $0.7^{\circ} \mathrm{C}, 0.2^{\circ} \mathrm{C}, 1.5^{\circ} \mathrm{C}$ and $1.2^{\circ} \mathrm{C}$ for North, South East and West facing walls, respectively. The results indicate that the estimated CLTD values by the present model are very close to the estimated TETD results. The differences are due to having different procedures for calculating the cooling load by CLTD and TETD methods presented in the ASHARE manual. 


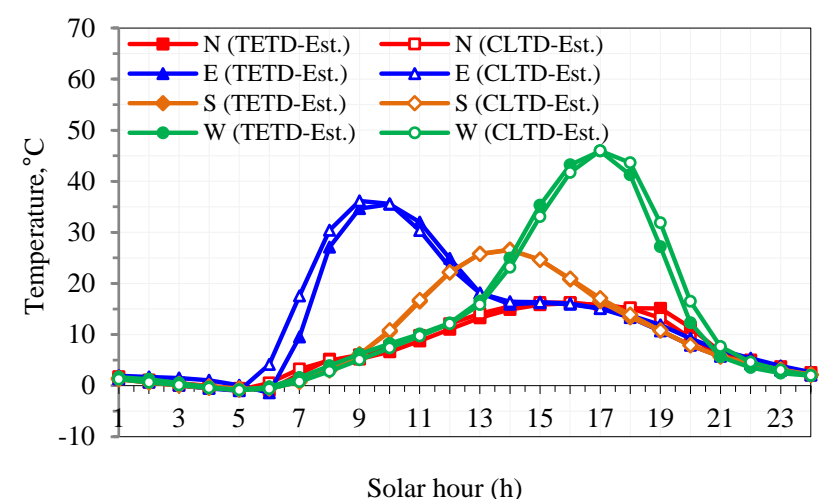

Figure 7. Variations of the estimated CLTD and TETD values for Wall 1.

Figure 8 indicates daily variations of the estimated CLTD and TETD values for Wall 3 . When the results are compared for Wall 3 , the average daily differences between CLTD and TETD values are $1.3^{\circ} \mathrm{C}, 0.9^{\circ} \mathrm{C}, 2.3^{\circ} \mathrm{C}$ and $2.5^{\circ} \mathrm{C}$ and for North, South, East, and West facing walls, respectively. When the calculated values for all the given walls are compared, it is seen that there are small differences for the North and South directions; however, a significant difference and also some phase difference is observed between the 6 a.m. and 6 p.m. for the East direction.

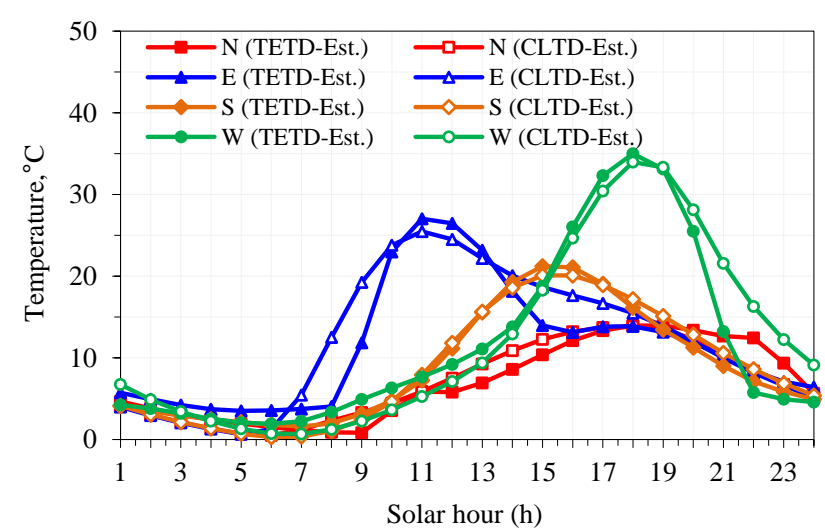

Figure 8. Variations of the estimated CLTD and TETD values for Wall 3

In this case, a comparison has been made between the estimated CLTD values and the estimated TETD values for Wall 9, as indicated in Figure 9. The average daily differences between CLTD and TETD values are calculated as $0.5^{\circ} \mathrm{C}, 2.4^{\circ} \mathrm{C}, 2.9^{\circ} \mathrm{C}$ and $1.1^{\circ} \mathrm{C}$ for North, South, East, and West facing walls, respectively. When the calculated values for all the given walls are compared, it is seen that there are small differences for the North and South directions; however, the significant differences and also different tendencies are observed for the East and West directions. In order to find out the differences, the nature of the procedures for calculating cooling by TETD and CLTD methods given in the 1997 ASHRAE Handbook of Fundamentals [17] should be examined.

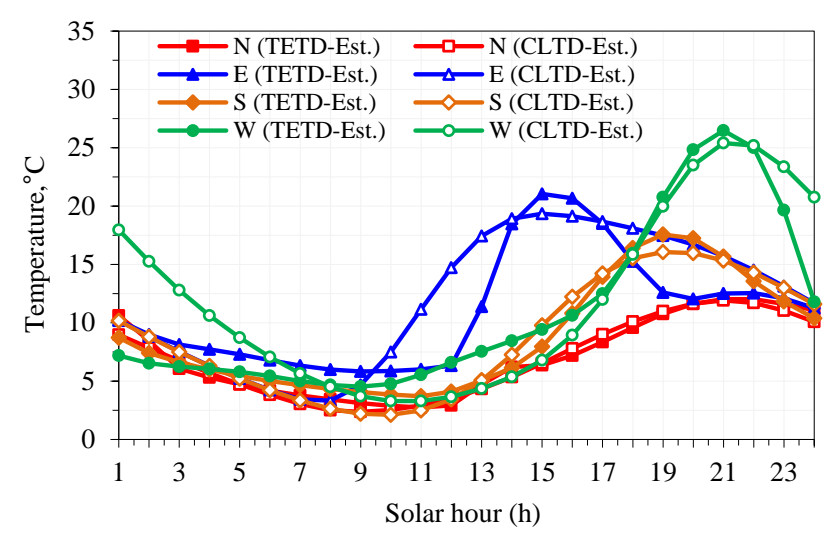

Figure 9. Daily variations of the estimated CLTD and TETD values for Wall 9

In order to investigate the differences between the methods, the time lags and decrement factors used in the TETD method are calculated for all directions and indicated in Figure 10. It is observed that the azimuth angle has a profound influence on time lag, which is also the most critical parameter in changing TETD values, while the azimuth has a small influence on the decrement factor. It is seen that there is an agreement between the calculated CLTD and TETD values for the given walls facing south and north directions. It is depicted from the Figure 9 that the time lag difference between East $(\gamma=-$ $\left.90^{\circ}\right)$ and South directions $\left(\gamma=0^{\circ}\right)$ was obtained as $1.7 \mathrm{~h}$, the difference was obtained as $1.9 \mathrm{~h}$ between West $\left(\gamma=90^{\circ}\right)$ and South, and finally the value of difference between South and North $\left(\gamma=180^{\circ}\right)$ directions was obtained as $0.6 \mathrm{~h}$.

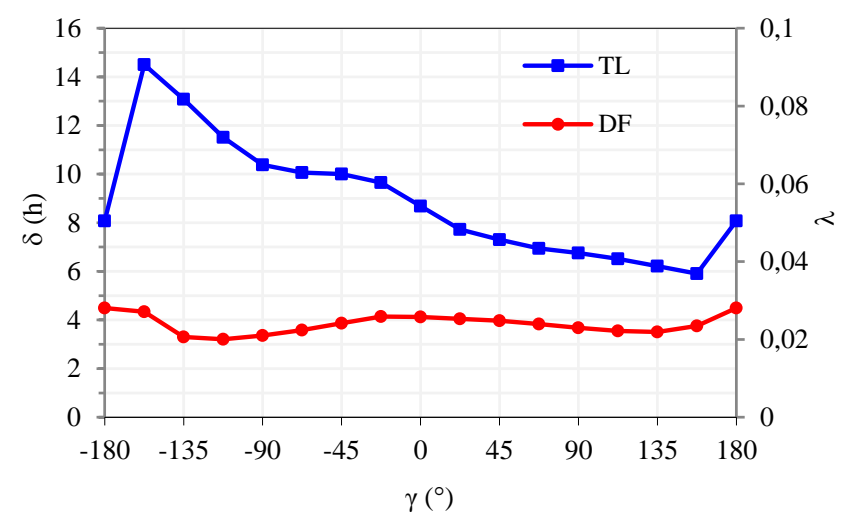

Figure 10. Variation of decrement factor and time lag values at different azimuth angles

Figure 11 shows the comparison of the heat gain values between obtained by the estimated TETD and CLTD from the present study and obtained by using Radiant Time Series method (RTS) taken from the 2009 ASHRAE Handbook of Fundamentals [19] with the values obtained by using for a south-facing wall (Spandrel Wall). Although widely different in approach, purpose, and mathematical processes, the results have many similarities, as indicated in Figure 11. In the comparisons, it is found that the maximum difference between the heat gains for the selected wall is less than $1 \%$. Therefore, the cooling load calculations methods given in ASHRAE [19] 
are compatible with each other, and there are some differences according to wall and roof types.

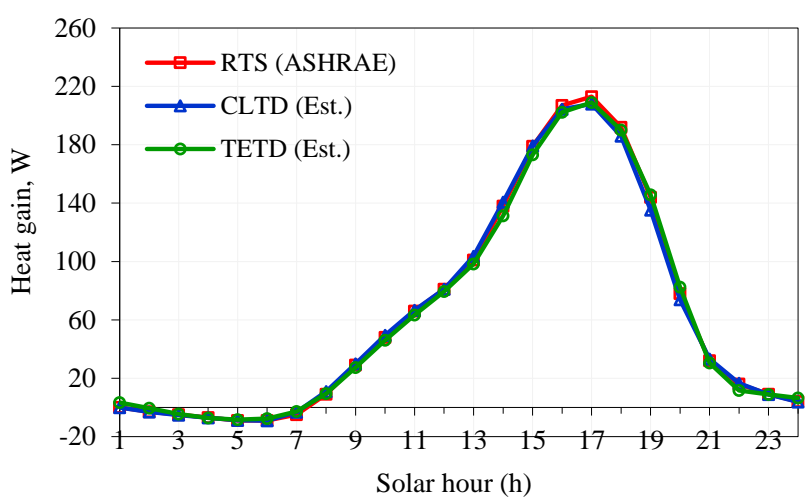

Figure 11. Comparison of heat gain values estimated by TETD and CLTD with RTS values given in ASHRAE 2009 [19] for a given structure.

\section{Conclusion}

In this study, the TETD and CLTD values for multilayer walls and flat roofs given in ASHRAE are compared with an analytical solution method obtained by the CFTT technique. The significant results are presented as follows:

$>$ The CLTD and TETD results obtained by the present model are in good agreement with those results presented in the ASHRAE manual for the given roofs. Furthermore, the estimated CLTD and TETD values by CFTT for selected wall structures facing different directions are compared. There is a good agreement between the results. Small differences are obtained for the North and South directions; however, the significant differences and also different tendencies are observed for the West and East directions. These differences can be due to the time lag values used in the TETD method.

$>$ From the present analysis, it can be concluded that the TETD method yields less accurate predictions than the CLTD method.

$>$ A comparison has been made between the gain values obtained RTS method in ASHRAE and estimated TETD and CLTD values. The results show that the cooling load calculations methods given in ASHRAE are compatible with each other. It is revealed that the transient solution of the heat transfer problem is beneficial to estimate RTS, CLTD, and TETD values for the given walls and roofs.

A program based on a periodic solution in MATLAB was developed to calculate CLTD, TETD, and heat gain values without using any standard table for any possible building envelope and external conditions. Furthermore, the CFFT method has many advantages for the given method in ASHRAE. Therefore, if the thermophysical properties of a building envelope and also the climate data for the cities are known, some specific CLTD and TETD values can be tabulated for the most important cities in the world for different building envelopes.

\section{References}

[1] Rudoy, W., Cuba, J.F., Cooling and heating load calculation manual, ASHRAE, 1979.

[2] Bansal, K., Chowdhury, S., Gopal, M.R., "Development of CLTD values for buildings located in Kolkata, India", Applied Thermal Engineering, 28, 1127-1137, 2008.

[3] Yumrutas, R., Unsal, M., Kanoglu, M., "Periodic solution of transient heat flow through multilayer walls and flat roofs by complex finite Fourier transform technique", Building and Environment, 40, 1117-1125, 2005.

[4] Wang, S.K., Handbook of air conditioning and refrigeration, McGraw-Hill, New York, 2001.

[5] ASHRAE, ASHRAE handbook-fundamentals, ASHRAE, Atlanta, 1993.

[6] Chaiyapinunt, S., Mangkornsaksit, K., and Phueakphongsuriya, B., "Development of cooling load temperature differential values for building envelopes in Thailand.", Journal of the Chinese Institute of Engineers, 27, 677-688, 2004.

[7] Alford, J.S., Ryan, J.E., Urban, F.O., "Effect of heat storage and variation in indoor temperature and solar intensity on heat transfer through walls", ASHVE Transactions, 45, 369-396, 1939.

[8] Mackey, C.O., Wright, L.T., "Periodic heat flowhomogeneous walls or roofs", ASHVE Transactions, 50, 293-312, 1944.

[9] Mackey CO, Wright LT. "Periodic heat flowcomposite walls or roofs", ASHVE Transactions, 52, 283, 1946.

[10] Yumrutaş, R., Kaşka, Ö., Yıldırım, E., "Estimation of total equivalent temperature difference values for multilayer walls and flat roofs by using periodic solution", Building and Environment, 42, 18781885, 2007.

[11] Ruivo, C. R., Ferreira, P. M., and Vaz, D. C., "On the error of calculation of heat gains through walls by methods using constant decrement factor and time lag values", Energy and Buildings, 60, 252-261, 2013.

[12] Zainal, O.A., and Yumrutas, R., "Validation of periodic solution for computing CLTD (cooling load temperature difference) values for building walls and flat roofs", Energy, 82, 758-768, 2015.

[13] Patrick, D.R., Energy Conservation Guidebook, Taylor \& Francis Ltd., London, 2007.

[14] McQuiston, F.C., Parker J.D., Heating, ventilating, and air conditioning, 4th ed., New York, Wiley, 1994.

[15] American Society of Heating, Refrigeration and Air Conditioning Engineers, ASHRAE, Handbook of Fundamentals, ASHRAE Product Directory, 1977 Fundamentals, Atlanta, GA: ASHRAE. 1977. 
[16] American Society of Heating, Refrigeration and Air Conditioning Engineers, ASHRAE, Handbook of Fundamentals, Atlanta, Ga, 1967.

[17] American Society of Heating, Refrigeration and Air Conditioning Engineers, ASHRAE, Handbook of Fundamentals, Chapter 28, Atlanta, 1997.
[18] MATLAB, Version. 8.5. 0.197613 (R2015a), The MathWorks Inc., Natick, Massachusetts, 2015.

[19] American Society of Heating, Refrigeration and Air Conditioning Engineers, ASHRAE, Handbook of Fundamentals, Chapter 18, Atlanta, 2009. 